Introduction: An important part of the therapeutic process of patients with lung cancer undergoing palliative chemotherapy is to assess their mental well-being. Evaluation of the sense of coherence and acceptance of the disease, which reflects the degree of adaptation of the patient to live with the disease, provides information on this topic.

Objective: The primary objective was to assess the level of sense of coherence and acceptance of the disease in patients with lung cancer during palliative chemotherapy as well as coherence and acceptance together with socio-demographic factors. The secondary objective was to assess the economic impact of lung cancer on these patients.

Material and methods: The study involved 100 patients with lung cancer during palliative chemotherapy. The study was conducted using the Sense of Coherence Questionnaire (SOC-29), the Acceptance of Illness Scale, and a socio-demographic questionnaire.

Results: The study group consisted mainly of men (66\%), people with primary/vocational education (63\%) and patients living in cities (59\%). The average age of respondents was 62.8 years. $45 \%$ of patients had a high level of sense of coherence, and $44 \%$ had an average level. The average overall score of SOC was 143.9 points inside the upper range of average results. Levels of a sense of comprehensibility, manageability, and meaningfulness remained in close relation to the average level: $48.91,51.33$, and 43.66 points, respectively. The average acceptance of the disease was $45 \%$ with the average total of 27.21 points.

Conclusions: Most patients during palliative chemotherapy because of lung cancer had average or high level of coherence and acceptance of the disease. The level of sense of coherence and acceptance of the disease was not affected by gender, age, education, or place of residence. Almost all patients incur costs associated with treatment, and in some of them the disease affected the source of income.

Key words: sense of coherence, acceptance of the disease, lung cancer, palliative chemotherapy.

Contemp Oncol (Pozn) 2019; 23 (3): 157-163 DOI: https://doi.org/10.5114/wo.2019.89243

\section{Sense of coherence and acceptance of the disease in patients with lung cancer during palliative chemotherapy}

\author{
Andrzej Nowicki ${ }^{1}$, Paulina Sianoszek ${ }^{1}$, Paulina Farbicka ${ }^{2}$
}

${ }^{1}$ Department of Oncology Nursing, Ludwik Rydygier Collegium Medicum in Bydgoszcz, Nicolaus Copernicus University in Torun, Bydgoszcz, Poland

${ }^{2}$ State Higher Vocational School in Koszalin, $10^{\text {th }}$ Military Research Hospital and Polyclinic in Bydgoszcz, Poland

\section{Introduction}

Lung cancer, known as a civilisation-related disease, is the most commonly diagnosed cancer and represents 13\% (1.6 million) of all detected cancers around the world. The number of cases of lung cancer was over 22,000 in Poland in 2014 [1]. Lung cancer is most often diagnosed in the advanced stage requiring pharmacological treatment. Palliative treatment relates primarily to patients in that period. Palliative chemotherapy is a component of palliative treatment that is directed primarily at relieving the symptoms. An important part of palliative treatment is to provide mental support to the patient and his/her family, assisting them to adapt to living with the disease, and recognising how patients perceive the situation in which they find themselves. Dysfunction of mental feelings that manifests usually in the form of emotional disorders like anxiety or depression can appear in the course of neoplastic disease [2]. In addition, little is known about how the sense of coherence and acceptance of the disease affect psychological well-being in various difficult life situations such as cancer with unfavourable prognosis.

The sense of coherence is a general human orientation that expresses the extent to which man has a durable and dynamic sense of confidence [3]. The components of the sense of coherence are a sense of comprehensibility, resourcefulness, controllability, and meaningfulness. The sense of understandability results from the fact that a person receives incoming information as coherent, orderly, and understandable. This process gives him/her the feeling that all life situations are subject to predictability and understanding. The sense of intelligibility is a cognitive variable. The sense of resourcefulness and controllability determines to what extent a person considers sufficient resources available to them to meet the requirements. The sense of meaningfulness defines to what extent a person sees the meaning of his life, determines the certainty that struggles with reality are worth the effort and commitment [4].

Another aspect of the well-being of oncological patients is mental adaptation to cancer and restoration of mental balance. This process takes place on two levels: cognitive and emotional [5]. Acceptance allows for a rational assessment of a difficult situation in which a patient is currently ill, which makes it possible to have a real impact on his/her health by taking up the fight against the disease. It is a long-term process that covers many aspects of a patient's life. Very often, it depends on individual personality traits and their resistance to stress. An elementary role in the process of adaptation to cancer is played by psychological resources and the ability to take advantage of the support offered [6].

Advanced cancer is very aggravating mentally, which consequently imposes on the medical staff need to take the efforts, which is adequate to communicate and care of patients with advanced lung cancer. The sense of 
Table 1 . The point range of the level of sense of coherence and its components

$\begin{array}{lcccc}\text { Level } & \text { A sense of coherence } & \text { Intelligibility } & \text { Resilience/control } \\ \text { Low } & 51-100 \text { points } & 11-33 \text { points } & 10-34 \text { points } \\ \text { Average } & 101-152 \text { points } & 34-50 \text { points } & 35-56 \text { points } \\ \text { High } & \text { above } 152 \text { points } & \text { above } 50 \text { points } & \text { Above } 56 \text { points }\end{array}$

Table 2. Scope of disease acceptance

$\begin{array}{lc}\text { Level } & \text { Points } \\ \text { Low } & 8-18 \\ \text { Average } & 19-29 \\ \text { High } & 30-40\end{array}$

Table 3. Socio-demographic data

\begin{tabular}{|c|c|}
\hline Variable & $n=\%$ \\
\hline $\begin{array}{l}\text { Sex } \\
\text { Woman } \\
\text { Man }\end{array}$ & $\begin{array}{l}34 \\
66\end{array}$ \\
\hline $\begin{array}{l}\text { Age } \\
\text { Up to } 50 \text { years } \\
\text { 50-65 years } \\
\text { Above } 65 \text { years }\end{array}$ & $\begin{array}{l}2 \\
61 \\
37\end{array}$ \\
\hline $\begin{array}{l}\text { Education } \\
\text { Primary/vocational } \\
\text { Secondary } \\
\text { Higher }\end{array}$ & $\begin{array}{c}63 \\
31 \\
6\end{array}$ \\
\hline $\begin{array}{l}\text { Place of residence } \\
\text { Village } \\
\text { City up to } 100,000 \\
\text { City above } 100,000\end{array}$ & $\begin{array}{l}41 \\
22 \\
37\end{array}$ \\
\hline $\begin{array}{l}\text { Professional activity } \\
\text { Working } \\
\text { Leisured } \\
\text { Pensioner }\end{array}$ & $\begin{array}{c}22 \\
9 \\
69\end{array}$ \\
\hline $\begin{array}{l}\text { Marital status } \\
\text { Single } \\
\text { Married } \\
\text { Widower/widow }\end{array}$ & $\begin{array}{c}13 \\
86 \\
1\end{array}$ \\
\hline $\begin{array}{l}\text { Change of livelihood } \\
\text { Yes } \\
\text { No }\end{array}$ & $\begin{array}{l}32 \\
68\end{array}$ \\
\hline $\begin{array}{l}\text { Incurrence of costs associated with treatment } \\
\text { Yes } \\
\text { No }\end{array}$ & $\begin{array}{c}89 \\
11\end{array}$ \\
\hline
\end{tabular}

coherence and acceptance of the disease play a significant role when experiencing stress, and cancer is a great source of this stress, particularly in the palliative treatment period. Therefore, the psychological reactions of patients to information about the disease are varied. Extremely negative reactions are caused by cancers affecting the main vital functions. That is in the case of lung cancer which mainly impairs breathing process [3].

The results of studies assessing the sense of coherence and the level of acceptance of the disease may contribute to the development of models of care, including the sphere of mental health in particular. In this way we can improve the quality of medical care, supporting the development of mental care area in patients with lung cancer. This is a very important aspect of holistic care in patients subjected to palliative chemotherapy, which focuses on terminally ill patients. This does not, however, lead to a cancer cure, which should be kept in mind in daily practice. The assessment of mental well-being is often forgotten as an important element of the therapeutic process of patients with lung cancer subjected to palliative chemotherapy. Thus, information on this subject can provide an assessment of the level of the sense of coherence and acceptance of the disease, which reflects the degree of the patient's adaptation to living with the disease.

The primary objective was to assess the level of sense of coherence and acceptance of the disease in patients with lung cancer during palliative chemotherapy, and relationships between coherence and acceptance and socio-demographic factors. Assessment of the economic impact of lung cancer on these patients was the secondary objective.

\section{Material and methods}

The study was conducted in the period from February to June 2017 on a group of 100 persons aged 50-65 years (median 64 years) diagnosed with lung cancer, who were undergoing palliative chemotherapy in the Department of Pulmonary Diseases and Treatment of Lung Cancer at the Kujawsko-Pomorskie Centre of Pulmonology in Bydgoszcz. Twenty-six people including 19 women refused to participate in the study. The study excluded eight people due to their poor general state of health. They were patients with serious side effects after chemotherapy and/or cognitive impairment. The entire group was tested in the period between the second and the fourth cycle of chemotherapy. These were patients who were initially qualified for chemotherapy because of the severity of the disease.

The study was approved by the Bioethics Committee of the Ludwik Rydygier Collegium Medicum in Bydgoszcz. The study used the Life Orientation Questionnaire (Sense of Coherence Questionnaire - SOC-29) by Antonovsky [7], the Acceptance of Illness Scale (AIS) in the adaptation of Juczyński [8], and an original socio-demographic questionnaire. SOC-29 consists of three components (sense of comprehensibility, resourcefulness, and meaningfulness), whose overall rating gives a complete picture of the global orientation of the patient. The questionnaire consists of 29 questions, of which 12 are questions with reverse scoring. Table 1 presents the point range of the level of the sense of coherence and its components. 
Table 4. The level of sense of coherence and its components

$\left.\begin{array}{lccc}\begin{array}{l}\text { Level of sense } \\ \text { of coherence }\end{array} & \begin{array}{c}\text { Coherence } \\ (n=\%)\end{array} & \begin{array}{c}\text { Comprehensibility } \\ (n=\%)\end{array} & \begin{array}{c}\text { Resourcefulness } \\ (n=\%)\end{array} \\ \text { Low } & 11 & 10 & 13 \\ (n=\%)\end{array}\right)$

The AIS, which reflects the degree of adaptation of the patient to living with the disease, consists of eight questions with five possible variants of numerical answers, where 1 means „strongly agree” and 5 means „strongly disagree". The scope of disease acceptance is presented in Table 2.

The study used a non-parametric Kruskal-Wallis rank test for comparison of many independent samples (in this case the place of residence of patients was the basis for determining the samples for analysis). The non-parametric Mann-Whitney $U$ test was also used to evaluate the differences between one feature between the two groups. The interdependencies between the two variables were calculated using the Spearman correlation coefficient $R$, age, and education. The arithmetic means value and standard deviation were also used. The level of $p \leq 0.05$ was accepted as statistically significant. All calculations and drawings were done using Statistica 10.0 and Microsoft Excel using the standard features of this software.

\section{Results}

\section{Socio-demographic characteristics of patients}

Men accounted for $66 \%$ of the respondents, and the average age was 62.8 years for men and 62.6 years for women. The largest group (61\%) were patients at the age of 51-65 years, and the least numerous (2\%) were under the age of 50 years. Due to the small size of the group, these patients were included in the age group of 50-65 years. Most patients (63\%) had primary/vocational education. Fewer respondents (41\%) lived in rural areas. Pensioners comprised $69 \%$, while $86 \%$ of patients were married. The disease had not affected the source of income in $68 \%$ of patients, while $89 \%$ of respondents had to incur the costs associated with treatment (Table 3).

\section{Sense of coherence}

Generally, patients had an average level of coherence, with a mean value of 143.9 points (upper zone of average results), and the $45 \%$ had a high level. The sense of comprehensibility, resourcefulness, and meaningfulness was at the level of average: $48.91,51.33$, and 43.66 points, respectively (Table 4).

Patients had the highest average score (5.63 points) for questions/statements concerning the sense of comprehensibility - answers to the first question, while the lowest average (3.88 points) was for answers to the third question. Of all the questions/statements about resource- fulness/controllability, patients had the highest average score average (5.88 points) for the answer to question 23, and the lowest average (4.74 points) for the $18^{\text {th }}$ statement. Regarding questions/statements about meaningfulness, the highest average score (6.01 points) was obtained for the response to statement number 16 (Table 5).

\section{The overall sense of coherence and sex, age, education, and place of residence}

Due to the large amount of data and the lack of statistical significance between the types of coherence and selected variables, the presented data covers the only an overall sense of coherence.

Most women (15 [44.1\%]) had a high sense of coherence, and the least (6 [17.6\%]) had low. Most women (31 [47\%]) had an average sense. The average score of SOC was similar in men and women $(p=0.585)$. Most patients at the age of $50-65$ years (30 [47.6\%]) had a high sense of coherence, while in the group over 65 years of age (18 [48.6\%]) the sense was at an average level. The average score of SOC was similar in both age groups $(p=0.576)$. Most respondents with primary/vocational education (33 [50.8\%]) had an average level of sense of coherence, while in the group with secondary /higher education, most (20 [54.1\%]) had a high sense. Average spot sense of coherence was similar among respondents with primary education /vocational and secondary/higher $(p=0.333)$. Most respondents living in rural areas (21 [51.2\%]) had an average level of coherence. Among the residents of cities with 100,000 residents and above, most patients had a high level of coherence: 11 (50\%) and 18 (48.6\%), respectively. Average scores for sense of coherence were similar among respondents living in the villages or towns with fewer than 100,000 residents ( $p=0.739$ ) (Table 6).

\section{Acceptance of the disease}

Of all the statements about acceptance of the disease, respondents rated the highest the sense that: sometimes disease makes me feel useless - average 4.17; and illness makes me a burden to my family and friends - average 4.11, while in contrast, the lowest sense that: I will never be self-sufficient to the extent to which I would like - average 2.75; and I think that people staying with me are often embarrassed because of my illness - average 2.72. The overall level of acceptance of the disease was average and amounted to 27.21 points (Table 7).

Twenty-eight men (42.4\%) had high or average level of acceptance of the disease, and 17 women (50\%) had av- 
Table 5. Average scores for answers to questions/statements in SOC questionnaire

\begin{tabular}{|c|c|c|c|}
\hline & No. & Question/statement & Mean/SD \\
\hline \multirow{11}{*}{ 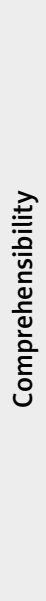 } & 1 & When you talk to people, do you have the feeling that they do not understand you? & $5.63 / 2.102$ \\
\hline & 3 & $\begin{array}{l}\text { Think of the people with whom you come into contact daily, aside from your relatives. How well do you know } \\
\text { most of them? }\end{array}$ & $3.88 / 2.475$ \\
\hline & 5 & $\begin{array}{l}\text { Whether happened in the past that you were surprised by people behaviour which as you thought } \\
\text { you well know? }\end{array}$ & $5.04 / 2.045$ \\
\hline & 10 & In the last ten years your life was... & $4.72 / 2.652$ \\
\hline & 12 & Do you feel that you are unfamiliar with unknown situation and you do not know what to do? & $4.72 / 2.446$ \\
\hline & 15 & When you face a difficult problem the choice of solution is... & $3.34 / 2.171$ \\
\hline & 17 & Your life in the future will probably be... & $3.65 / 2.591$ \\
\hline & 19 & Do you have mixed feeling and thoughts? & $4.04 / 2.546$ \\
\hline & 21 & Does it happen that you have feelings inside you would rather not have? & $4.95 / 2.426$ \\
\hline & 24 & Do you feel that you do not know exactly what's going to happen? & $4.27 / 2.453$ \\
\hline & 26 & When something happened, you claimed usually that... & $4.67 / 2.543$ \\
\hline \multirow{10}{*}{ 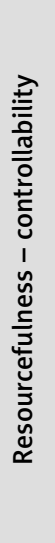 } & 2 & $\begin{array}{l}\text { In the past, when you had to do something that depended on collaboration with other people, do you } \\
\text { feel that... }\end{array}$ & $4.82 / 2.467$ \\
\hline & 6 & Did it happen that people whom you counted on disappointed you? & $5.45 / 1.789$ \\
\hline & 9 & Do you feel that you are being treated unfairly? & $4.39 / 2.593$ \\
\hline & 13 & What best describes your way of looking at life? & $5.43 / 2.09$ \\
\hline & 18 & When something unpleasant happened in the past you were willing to... & $4.74 / 2.573$ \\
\hline & 20 & When you do something that puts you in a good mood... & $5.56 / 2.148$ \\
\hline & 23 & Do you think that in the future there will always be people whom you can count on? & $5.88 / 1.919$ \\
\hline & 25 & $\begin{array}{l}\text { People, even with a strong character, sometimes feel losers in certain situations; how often have you felt like } \\
\text { this in the past? }\end{array}$ & $5.19 / 2.019$ \\
\hline & 27 & When you think about the difficulties that you may face in the important areas of your life, do you feel that... & 4.6/1.775 \\
\hline & 29 & How often do you have feelings that you do not know if you can control? & $5.27 / 2.233$ \\
\hline \multirow{8}{*}{ 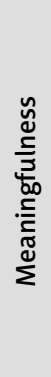 } & 4 & Do you have the feeling that you really do not care what is going on around you? & $5.15 / 2.516$ \\
\hline & 7 & The life is... & $6 / 1.907$ \\
\hline & 8 & So far in your life... & $5.79 / 1.971$ \\
\hline & 11 & Most of what you will be doing in the future will probably be... & $4.88 / 1.695$ \\
\hline & 14 & When you think about your life, very often... & $5.63 / 2.097$ \\
\hline & 16 & Performing daily activities is a source of ......... for you & $6.01 / 1.389$ \\
\hline & 22 & You anticipate that your personal life in the future will be... & $4.98 / 2.225$ \\
\hline & 28 & How often do you feel that what you do every day is not very meaningful? & $5.22 / 1.998$ \\
\hline
\end{tabular}

erage level of acceptance. Average acceptance of the disease was similar in men and women $(p=0.899)$. The high degree of acceptance of the disease among respondents over 65 years of age was 15 (40.5\%) and in the age group of 50-65 years - 26 (41.3\%) patients. Average acceptance of the disease was similar in both sexes $(p=0.659)$. Nineteen $(51.4 \%)$ patients with secondary/higher education and 22 (34.9\%) patients with primary/vocational education had a high level of acceptance of the disease. The average acceptance of the disease in both education groups were similar $(p=0.074)$. Sixteen (39\%) patients living in rural areas, 15 (40.5\%) living in cities with more than 100,000residents, and $10(45.5 \%)$ living in a town/village with fewer than 100,000 residents had a high acceptance of the disease. The average level of acceptance of the disease was independent of the place of residence ( $p=0.853$ ) (Table 6). The overall average level of acceptance of the disease was $45 \%$ of respondents, a high $-41 \%$, and low $-14 \%$ of patients.

\section{Discussion}

The largest group of respondents had a high or average level of coherence. This may prove the understanding of current events by patients, their high sense of resourcefulness, and the reasonableness of involvement in the daily hardships of life with the disease and creating future prospects. Components of the sense of cohesion remained together in certain connections, which was reflected in the obtained results. The same number of respondents had an average level of a sense of comprehensibility, resourcefulness, as well as a sense of meaningfulness. A sense of reasonableness was considered as the most important component because it affects the level of increase or de- 
Table 6. The patient's SOC and selected variables

\begin{tabular}{|c|c|c|c|c|c|c|c|c|c|}
\hline \multicolumn{2}{|l|}{ SOC level } & \multicolumn{2}{|c|}{ Low } & \multicolumn{2}{|c|}{ Average } & \multicolumn{2}{|c|}{ High } & \multirow[t]{2}{*}{ Mean/SD } & \multirow[t]{2}{*}{$p$} \\
\hline Variable & Position & $n$ & $\%$ & $n$ & $\%$ & $n$ & $\%$ & & \\
\hline \multirow[t]{2}{*}{ Sex } & Female & 6 & 17.6 & 13 & 38.2 & 15 & 44.1 & $140.7 / 33.75$ & \multirow[t]{2}{*}{0.585} \\
\hline & Male & 5 & 7.6 & 31 & 47 & 30 & 45.5 & $145.5 / 29.12$ & \\
\hline \multirow[t]{2}{*}{ Age } & 50-65 years & 7 & 11.1 & 26 & 41.3 & 30 & 47.6 & $145.06 / 33.1$ & \multirow[t]{2}{*}{0.576} \\
\hline & Above 65 years & 4 & 10.8 & 18 & 48.6 & 15 & 40.5 & $141.92 / 28.7$ & \\
\hline \multirow[t]{2}{*}{ Education } & Primary/vocational & 6 & 9.5 & 32 & 50.8 & 25 & 39.7 & $142.08 / 30.4$ & \multirow[t]{2}{*}{0.333} \\
\hline & Secondary/higher & 5 & 13.5 & 12 & 32.4 & 20 & 54.1 & $147.0 / 32.28$ & \\
\hline \multirow{3}{*}{$\begin{array}{l}\text { Place of } \\
\text { residence }\end{array}$} & Village & 4 & 9.8 & 21 & 51.2 & 16 & 39 & $143.46 / 26.4$ & \multirow[t]{3}{*}{0.739} \\
\hline & City up to 100,000 & 2 & 9.1 & 9 & 40.9 & 11 & 50 & $144.50 / 31.3$ & \\
\hline & City above 100,000 & 5 & 13.5 & 14 & 37.8 & 18 & 48.6 & $144.03 / 37.1$ & \\
\hline
\end{tabular}

crease in other components. When a sense of meaningfulness is strong, the other two components of Antonovsky's theoretical construct show an upward trend. However, if the sense of meaningfulness is at a low level, then all the components tend to fall [9]. Generally, oncological patients have a high level of coherence. This also applies to patients diagnosed with cancer, who are waiting to start treatment with ionising radiation [10].

Almost half of the women had a high level of sense of coherence, while among men the average level was most frequent. It can be concluded that in patients whose sense of coherence was low, the disease caused significant changes in their lives. This raises suspicion about the vulnerability of some patients to a very strong stressor - an incurable stage of the disease. In this case, determination the level of sense of coherence can set up the scope of care according to the patient's needs.

The study shows that patients with cancer have a lower level of coherence in comparison with other groups of patients [11, 12]. However, according to others, even though the sense of coherence is considered to be a stable but dynamic variable, the level of coherence may be reduced by the adoption of the negative message and increase as a result of the planning or the participation in treatment alone. A significant increase in the sense of cohesion was observed even after the intervention of nursing. There is a need for additional support on the mental plane in patients with lower levels of SOC [13]. Analysing the results of various studies on the importance of a sense of coherence, it can be said that an important element is to conduct health education among patients in order to increase the level of sense of coherence [14]. In addition, the level of knowledge on the subject possessed by medical staff and the proper way to transfer this knowledge to patients has a significant influence on adaptation to the disease [15].

There was no statistically significant correlation between the level of sense of coherence and sex, age, education, or place of residence. Similar results were obtained by authors from the University of Philadelphia. Their study involved 172 patients (122 patients with cardiovascular diseases and 50 patients with cancer). It is surprising that there are no differences between the two study groups in relation to the level of coherence. Additionally, oncology
Table 7. Average scores for statements of disease acceptance scale

\begin{tabular}{|c|c|c|}
\hline No. & Statement & Mean/SD \\
\hline 1 & $\begin{array}{l}\text { I have trouble adjusting to the limitations } \\
\text { imposed by the disease }\end{array}$ & $3.44 / 1.828$ \\
\hline 2 & $\begin{array}{l}\text { I am not able to do what I like the most } \\
\text { because of my health state }\end{array}$ & $2.79 / 1.833$ \\
\hline 3 & Sometimes disease makes me feel useless & $4.17 / 1.464$ \\
\hline 4 & $\begin{array}{l}\text { Health problems make me more dependent } \\
\text { on others than I want }\end{array}$ & $3.22 / 1.779$ \\
\hline 5 & $\begin{array}{l}\text { Illness makes me a burden for my family } \\
\text { and friends }\end{array}$ & $4.11 / 1.476$ \\
\hline 6 & $\begin{array}{l}\text { My health state makes me feel not like } \\
\text { a full-blown man }\end{array}$ & $4.01 / 1.547$ \\
\hline 7 & $\begin{array}{l}\text { I will never be self-sufficient to the extent } \\
\text { to that I would like }\end{array}$ & $2.75 / 1.743$ \\
\hline 8 & $\begin{array}{l}\text { I think that people staying with me are } \\
\text { often embarrassed because of my illness }\end{array}$ & $2.72 / 1.741$ \\
\hline & Overall average & $27.21 / 8.322$ \\
\hline
\end{tabular}

patients have only a slightly lower level of coherence in comparison to the healthy population [16].

Psychometric properties of the scale of acceptance of the disease indicate that it is an accurate predictor of the quality of life conditioned by the disease, identifying with a sense of satisfaction with life and with the assessment of the current state of health. The higher the level of acceptance of the disease, the better the adaptation to the disease and the lower the sense of psychological discomfort [17]. Among our patients, almost half of them accepted the disease at an average level, slightly fewer at a high level, and only a few had a low level of acceptance. Other reports indicate otherwise and show that only $25 \%$ of cancer patients accept the disease, which often refers to the oldest age group [18]. We found no statistically significant correlation between the level of acceptance of the disease and sex, age, education, or place of residence. Similar results were obtained by the authors of other research - in which no difference between patients of both sexes, their age, education, and professional status were found [19].

Slightly different results were obtained by other authors in young patients with cancer (mean age 34.34 
\pm 9.47 years). Age and the degree of religiosity of respondents had an influence on the degree of acceptance [20]. The low level of acceptance of the disease at a relatively young age can result from the failure of some sense of social roles or the loss of existing plans and aspirations and can also be the result of the shock accompanying diagnosis. Regarding the acceptance of the disease, most people answered negatively to the statement: disease sometimes makes me feel useless. This indicates that the patient has a sense of their own usefulness within the family and society despite the poor prognosis. It is important to proceed with the patient in order to strengthen this feeling. Most respondents agreed with the statement: I think that people staying with me are often embarrassed because of my illness. This is very important for medical staff and people from the patient's environment. Conversations about incurable disease, suffering, and existential or physical death are still taboo. Such subjects are often avoided as a result of inadequate preparation for the holistic care of an incurable disease. Communication between medical staff, the patient's family, and the patient requires many changes, acquiring new skills, and above all theoretical preparation.

Besides the psycho-physical aspect of adaptation to cancer and its acceptance, the economic aspect is an important element that should be noted. They were asked whether the disease has affected livelihoods and whether patients incurred costs associated with the treatment. Almost all of them bore the costs associated with the treatment of cancer, and almost every third patient experienced a change of source of income as a result of the disease. The vast majority of patients reported a reduction of economic status. This problem was publicised after the publication of the study "Cancer - patient experience”, which was the largest qualitative study conducted in recent years in Poland. The report illustrates the different facets of the disease from the perspective of patients undergoing long-term oncological treatment that involves an additional mental and financial burden. Basic drugs are usually reimbursed, while costs associated with transportation, specialised diet, and hygienic supplies can exceed the financial capacity of patients and their families [20]. It is obvious that the financial problem largely affects the mental well-being of the patient. It is impossible to accept the disease and resign oneself to disease in a situation where a patient has inadequate funds to cover the costs arising therefrom. Often the patient's awareness that it is impossible to prolong life or improve its quality in the absence of financial resources is unacceptable.

Finally, it should be remembered that during the recruitment (which can be a certain limitation) 25\% of patients were not included in the study; these were patients who refused or did not qualify because of their health condition. Nevertheless, in our opinion, the study can be generalised. To obtain the appropriate number in the group, the study was carried out in two centres. It should be emphasised that they were patients with advanced lung cancer during toxic chemotherapy. Due to the basic illness, treat- ment, and specific time of the examination, recruitment in such cases always has its limitations.

\section{Conclusions}

1. The majority of patients during palliative chemotherapy because of lung cancer had an average or high level of coherence and acceptance of the disease.

2. The level of coherence and acceptance of the disease were not affected by gender, age, education, and place of residence.

3. Almost all patients bore the costs associated with treatment, and in some of them the disease affected their livelihoods.

\section{Acknowledgments}

The authors thank the employees of the Department of Pulmonary Diseases and Treatment of Lung Cancer at Kujawsko-Pomorskie Centre of Pulmonology in Bydgoszcz for allowing access to patients for the study.

The authors declare no conflict of interest.

\section{References}

1. Didkowska J, Wojciechowska U, Zatoński W. Nowotwory złośliwe w Polsce w 2011 roku. Centrum Onkologii - Instytut im. M. Skłodowskiej-Curie, Warszawa 2013.

2. Majkowicz M. Wybrane problemy psychoonkologii z uwzglednieniem zagadnień psychiatrycznych. Psychiatr Psychol Klin 2008; 1: 57-66.

3. Kurowska K, Weilandt K. Poczucie koherencji a radzenie sobie z chorobą u osób z rozpoznaniem raka płuca. Probl Pielęg 2010; 1: 11-16.

4. Januszewski A. A comparison of the classical and hierarchical sense of coherence model in The Multidisciplinary Approach to Health and Disease. CPPP Scientific Press, Lublin 2011: 236-251.

5. Juczyński Z. Narzędzia pomiaru w promocji i psychologii zdrowia. Pracownia Testów Psychologicznych PTP, Warszawa 2008.

6. Kamińska M, Pawlak-Warszawska A, Baczewska B, Bronikowska A, Ferańska M. Wydolność pacjentów z chorobą nowotworową a akceptacja choroby. Studia Medyczne 2014; 30: 6-13.

7. Koniarek J, Dudek B, Makowska Z. Kwestionariusz Orientacji Życiowej. Adaptacja The Sense of Coherence Questionnaire (SOC) A. Antonovsky'ego. Przegląd Psychologiczny 1993; 36: 491-502.

8. Juczyński Z. Narzędzia pomiaru w promocji i psychoonkologii zdrowia. Skala akceptacji choroby - AIS. Pracownia Testów Psychologicznych Polskiego Towarzystwa Psychologicznego. Warszawa 2009, 162-166.

9. Heszen I, Sęk H. Psychologia zdrowia. Wydawnictwo Naukowe PWN, Warszawa 2008: 76-89.

10. Kurowska K, Dahms S, Głowacka M, Haor B. Poczucie koherencji a depresyjność u osób z chorobą nowotworową. Psychogeriatria Polska 2010; 7: 91-98.

11. Kurowska K, Jaworska M. Poczucie koherencji (SOC) a style radzenia sobie z chorobą u osób z rozpoznaniem raka jajnika i jądra. Probl Pielęg 2010; 18: 429-434.

12. Rynkiewicz-Andryśkiewicz M, Andryśkiewicz P, Curyło M, Czernicki J. Analiza przydatności oceny poziomu poczucia koherencji w chorobach somatycznych i psychicznych. Przegląd Medyczny Uniwersytetu Rzeszowskiego i Narodowego Instytutu Leków w Warszawie, Rzeszów 2014; 4: 365-374.

13. Oxelmark L, Magnusson A, Lofberg R, Hilleras P. Based intervention program in inflammatory bowel disease patients: effect on quality of life. Inflammatory Bowel Dis 2007; 13: 182-190. 
14. Kurowska K, Czepek K. Poczucie koherencji(SOC) a preferowane style radzenia sobie $z$ chorobą $u$ osób z rozpoznaniem kamicy żółciowej. Now Lek 2009; 78: 300-306.

15. Kurowska K, Sulkowska J. Poczucie koherencji a zachowania zdrowotne wśród pensjonariuszy Domu Pomocy Społecznej (DPS) - badania wstępne. Psychogeriatria Polska 2011; 2: 21-29.

16. Bruscia K, Shultis C, Dennery K, Dileo C. The sense of coherence in hospitalized cardiac and cancer patients. J Holist Nurs 2008; 26 : 286-294.

17. Juczyński Z. Psychologiczne wyznaczniki przystosowania się do choroby nowotworowej. Psychoonkologia 1997; 1: 22-27.

18. Pacian A, Kulik TB, Skórzyńska H. Rola wsparcia w bólu nowotworowym. Med Paliat 2014; 6: 95-100.

19. Czerw Al, Bilińska M, Deptała A. The assessment of the impact of socio-economic factors in accepting cancer using the Acceptance of Illness Scale (AIS). Contemp Oncol 2016; 20: 261-265.

20. Kołpa M, Wywrot-Kozłowska B, Jurkiewicz B, Grochowska A. Czynniki determinujące akceptację i przystosowanie do choroby nowotworowej. Piel Chir Angiol 2015; 3: 165-169.

\section{Address for correspondence}

\section{Andrzej Nowicki}

Department of Oncological Nursing

Ludwik Rydygier Collegium Medicum in Bydgoszcz

Nicolaus Copernicus University in Torun

1 tukasiewicza St.

85-821 Bydgoszcz, Poland

e-mail: anow1_xl@wp.pl

Submitted: 19.11 .2018

Accepted: 14.06.2019 